\title{
Determinants of Bank Branch Presence in Local Areas: A Comparison Between North and South of Italy
}

\author{
Laura Barbieri ${ }^{1}$, Mariarosa Borroni ${ }^{2}$, Andrea Lippi ${ }^{1}$, Mariacristina Piva ${ }^{1} \& \operatorname{Simone~Rossi~}^{1}$ \\ ${ }^{1}$ Faculty of Economics and Law, Università Cattolica del Sacro Cuore, Piacenza, Italy \\ ${ }^{2}$ Faculty of Economics, Università Cattolica del Sacro Cuore, Milan, Italy \\ Correspondence: Simone Rossi, Università Cattolica del Sacro Cuore, Via E. Parmense, 84, Piacenza, Italy. Tel: \\ 390-523-599-301. E-mail: simone.rossi@unicatt.it
}

Received: June 9, 2021

Accepted: July 21, 2021

Online Published: July 25, 2021

doi:10.5539/ijef.v13n9p15

URL: https://doi.org/10.5539/ijef.v13n9p15

\begin{abstract}
A close relationship with customers, mainly achieved through the opening of local branches, has long been a fundamental key to competitive advantage in the banking sector. Financial innovation, changes in customer behavior and competitive dynamics have transformed this relationship over time, leading to the closure of numerous branches. This work explores the determinants of branch evolution in an advanced and notoriously bank-centric country (Italy) using NUTS 3 panel data over the 2000-2016 time-span. Results show how - in general - demographic, industrial and economic variables explain the dynamics of banks' branch location strategy. However, more heterogeneous evidence emerges when North and South Italy are taken into consideration separately suggesting that territorial and regional dimension might play a role even in the banking sector.
\end{abstract}

Keywords: banking, bank branches, market structure, competition

\section{Introduction}

Even though developments in information technology have reduced the importance of geographical location, a firm's physical proximity to its customers still remains a crucial element for safeguarding competitive advantage and providing better services. This is particularly true for the banking sector, where service quality is much influenced by the interaction between customers and bank staff. The opening of new offices can both strengthen the presence of an incumbent bank in a certain area (increasing its market power) and conversely, contribute to reducing concentration indexes (thanks to the entry of new players). The literature has highlighted the importance and the role of bank branches in customer relations; in addition, some contextual variables that can influence the opening and the closing of bank branches have been identified.

Using a wide-ranging dataset of economic and social variables referred to Italian provinces (NUTS 3) over the period 2000-2016, the aim of the research presented in this paper is to analyse the attractiveness of different geographical areas for the banking system. Three main policy implications deriving from our results are identifiable. Firstly, suggestions are made for local policy-makers interested in evaluating the degree of attractiveness of their local area to the financial sector. Secondly, the banking sector can find information about local market features that explain the dynamics observed in branch presence during the past decade. Finally, national regulators and policy-makers can obtain useful hints for tackling branch desertification and financial exclusion issues.

The paper is organized as follows: Sections 2 reviews the literature on bank spatial competition; Section 3 describes our variables and methodology issues. Our results are presented in Section 4 and discussed in Section 5, where the main conclusions are given.

\section{Literature Review}

Elyasiani and Goldberg (2004) present a comprehensive review of the literature on the importance of the bank-client relationship to the banking sector. More in detail, they demonstrate that relationship banking increases the availability of funds and reduces loan rates. Moreover, small banks are able to maintain the advantages of relationship banking in spite of technological changes. In this stream of literature and from the point of view of the customer, according to Degryse and Ongena (2005) and Degryse et al. (2009) physical 
closeness creates better conditions for searching for potential borrowers and depositors and monitoring bank-firm relationships and loan officers' activities. More generally, many studies (e.g. Petersen \& Rajan, 2002; Breevort \& Hannan, 2006; Agarwal \& Hauswald, 2010; Ho_Ishii, 2011) argue that spatial proximity can affect loan pricing and the likelihood of loan approvals. Moreover, from the point of view of the bank, physical closeness may be an important source of market power for competitive reasons (Richards et al., 2008).

Since the seminal work by King and Levine (1992), the empirical and theoretical literature has investigated the relationship between bank branch presence and the socio-economic conditions of a specific area (the so-called "finance-growth nexus"). In this framework, greater levels of bank density in a specific area are associated with better economic conditions, including GDP growth. Moreover, the existence of branch networks prevents the advent of financial exclusion phenomena. Referring to this latter problem, Alamá et al. (2013) point out that branch rationalization processes observed in Spain might have exacerbated the consequences of the crisis for some social groups; several other papers assess the risks of bank desertification both for the banking industry and local communities (Argent-Rolley, 2000; Leyshon et al., 2008; Alamà \& Tortosa-Ausina, 2012; Ding \& Reid, 2020. See also Dante \& Makridis, 2021 for a study about mobile banking vs brick and mortar branches in tackling financial exclusion). Not surprisingly, these close links between the financial system and the socio-economic conditions of a certain area in turn become elements of great concern for regulators and policy-makers. In line with this view, Burgstaller (2013) postulates that since bank efficiency and competition seem to be indicative of stronger regional growth, "the preservation of a fair regional bank outreach appears to be an important policy target". Huysentruyt et al. (2012) explore the determinants of the patterns of bank presence in the neighbourhoods of Antwerp between 1991 and 2006. Their empirical results show that, in addition to market structure conditions, the socio-economic environment also has a high influence on branching decisions; these outcomes are confirmed by several recent papers (among others Qi et al., 2019; Sengupta and Dice, 2019; Chen \& Strathearn, 2020; Stix, 2020)

Argent and Rolley (2000), Felici and Pagnini (2008), Okehalam (2009), Cohen and Mazzeo (2010), Alamà and Tortosa-Ausina (2012), Huysentruyt et al. (2013) and Alamà et al. (2015) argue and demonstrate that the number of inhabitants is a factor influencing attractiveness for bank branches. However, analysing Portuguese bank branching decisions between 1988 and 1996, Barreto and Badenfuller (2006) find that banks also imitate their legitimacy-based groups towards unattractive locations, producing a negative effect on profitability. This result is consistent with the conclusions of Chang et al. (1997): studying bank branch openings in New York City in the period 1990-1995, these authors find a "bandwagon behaviour" that appears to reduce branch profits. He and Yeung (2011), studying a panel of foreign banks operating in China, observe a "rational herding conduct": smaller players tend to follow their customers, while larger banks are likely to adopt a 'follow-the-competitor' strategy.

Since the introduction of deregulation measures regarding the Italian banking system (1991), several papers have empirically investigated the socio-economic and competitive conditions that have determined branch dynamics. Italy is a perfect candidate for this kind of analysis because of its bank-centric system, observable in its highly branched and strongly relationship-based banking tendencies. Calcagnini et al. (2002), studying the reasons for de-novo branch openings for the years 1992-1996 in Italy, find that this choice is influenced by several factors, including the existing market structure, the past branch expansion of the bank and its competitors and the existence of unserved municipalities in the target province. Using a sample of 300 Italian banks during the period 1991-2002, Felice and Pagnini (2008) show that banks are more likely to expand into those markets that are closest to their pre-entry locations. Coccorese (2012), by examining a wide sample of large and medium Italian banks during the period 1995-2009, finds that banks behave as "fat cats", overinvesting in the branch network so as to keep prices high and accommodate entry. Thanks to the advent of information and communication technologies, banks have also become increasingly able to open branches in distant markets. Supporting this view, Carmignani et al. (2020), studying branch dynamics in Italy during the period 2012-15, find that closures have been more intensive where online banking services were more widely used by customers.

\section{Data and Hypotheses}

We analyse the determinants that explain the presence of bank branches in Italy during the period 2000-2016 at a provincial level (NUTS 3) using several socio-economic factors as explanatory variables. This information comes from different sources: the Italian National Institute of Statistics (ISTAT), the Bank of Italy and the Italian Chambers of Commerce (InfoCamere). Our dependent variable is the number of bank branches that are present in a specific province, provided by the Bank of Italy. This variable is a well-known and unambiguous indicator of geographical banking presence. 
Explanatory variables of the number of bank branches at the provincial-level have been grouped into two sets: one related to socio-economic characteristics and the other one more industry-specific.

Referring to the socio-economic dimension, the following determinants have been considered:

- Elderly index: this measure is calculated dividing the population over 64 years old by the population between 15 and 64 years old (source: ISTAT). Being the latter cohort a proxy for active population, the variable can be interpreted as a "dependency index". The use of measures based on age ranges to explain the attractiveness of an area for the banking sector is frequent in literature (Chang et al. 1997; Huysentruyt et al., 2013). Usually, elderly people are seen as a priority target for brick-and-mortar bank offices. In effect, they are usually more prone to retain higher deposits and to prefer a face-to-face interaction with a bank. Hence, we expect a positive sign for the coefficient associated with this variable.

We formulate the following hypothesis:

Hla: the older the population in a specific area, the higher the number of bank branches in that area.

- Youth index: the nature of this variable is similar to the previous one. In this case we identify youth with population below 15 years old (source: ISTAT). Although Elderly and Youth indexes share a common computation methodology and are both dependency indicators, their interpretation is different. In effect, young people are typically characterized by low wealth and prefer automated - technological interaction with the banking system. In this sense, we may expect a negative sign for the coefficient associated to this variable.

HIb: the younger the population in a specific area, the lower the number of bank branches in that area.

- Population: In order to consider the overall effect of population in each province (source: ISTAT), we expect that larger provinces (in terms of population) require a higher number of branches. However, as long as a huge number of M\&A has affected the bank system, there might be also a rationalization effect more effective in large provinces than in small ones (Coccorese \& Santucci, 2020). Therefore, the higher number the resident population in an area could determine a higher number of bank branches in that area, even if recent M\&A operations are operative in large cities and they might cause an opposite effect.

The general hypothesis is:

H2: the higher the resident population of an area, the higher the number of bank branches in that area.

- Value Added: this variable measures the real Value Added per capita (source: ISTAT) and in our model accounts for the economic output capacity of a specific area. Several papers, starting from King and Levine (1992), make use of GDP figures to control for macroeconomic conditions and growing potential. However, a complete time series for GDP at the provincial level is not available for Italy in the period under investigation. Value Added - generally highly correlated with GDP - can be considered a valid proxy for wealth per-capita.

Our hypothesis is therefore:

H3: the higher the ability of an area to produce significant wealth, the greater the number of bank branches in that area.

- Industry vitality: in order to take into consideration, the sectoral-composition of each province, the industry vitality variable is included. This item is equal to the difference between birth rate and mortality indexes (source: InfoCamere - Note 1) for firms in the primary sector, manufacturing and services. In this sense, it identifies these latter industries' attitude to renewal. We, therefore, include three different variables (Vit primary, Vit manufacturing, Vit services), each one accounting for a different macro-sector. Alamà and Tortosa-Ausina (2012), studying the determinants of bank presence in Spain after the liberalization of branch openings, employ several measures to account for the development of economic sectors (this approach was inspired by the seminal work by Crawford, 1973). The three measures of vitality signal the health and dynamics of the respective sector and, more generally, of the local economy. We, therefore, expect:

H4: the higher the vitality indexes, the greater the number of bank branches in that area.

Turning to the bank-industry variables, the following are considered:

- Leader market share: this variable captures the competitive conditions and is equal to the highest share of branches held by a single bank or banking group in the area under examination (source: our elaboration on Bank of Italy's data). Concentration is usually measured in literature through the Herfindahl Hirschman Index. However, this indicator has several well-known drawbacks (for example, it assumes the same value for very different market share configurations). Hence, we prefer to use a variable that provides a clear-cut view of the leader bank market power. A high concentration level may deter new branch openings or determine office 
closing, due to a "saturation effect" and to the dominant position that the leader can exert on the territory (this is usually the case of local banks in rural areas). At the same time the existence of a recognised leader should stimulate other banks to start a hostile strategy based on physical presence on the territory. Indeed, the leader itself should overinvest in its branch network to prevent this advance. While it is clear that concentration has an effect on branch opening and closing decisions, the expected sign of the coefficient associated is still unclear.

All in all, we assume that:

\section{H5: higher leader market share might reduce the overall number of branches in a province.}

- Deposits: this variable includes money deposits from non-monetary institutions (source: Bank of Italy). Deposits and credits are widely recognized as being a proxy of the workload of a traditional commercial bank. Yet, time series on outstanding credit lines have frequent interruptions caused by changes in data collection criteria. Felici and Pagnini (2008) and He and Yeung (2011) follow this approach and find a positive relationship between total deposits and branch presence. Therefore, we formulate this hypothesis:

H6: the higher the level of customer deposits, the greater the bank presence through brick-and-mortar branches.

Table 1 lists and describes the variables used in this study.

Table 1. List and description of variables

\begin{tabular}{ll}
\hline Variables & Description \\
\hline Branches & Number of branches located in a province \\
Elderly Index & Population over 64 years old divided by population between 15 and 64 years old \\
Youth Index & Population below 15 years old divided by population between 15 and 64 years old \\
Pop desert & Dummy variable: $=1$ if population is below 200,000 units \\
Pop low & Dummy variable: $=1$ if population is between 200,000 and 500,000 units \\
Pop mid & Dummy variable: $=1$ if population is between 500,000 and 1 million units \\
Pop high & Dummy variable: $=1$ if population is above 1 million units \\
Value Added & Real Value Added per capita \\
Vit primary & Difference between nativity and mortality rate for firms belonging to the primary sector \\
Vit manufacturing & Difference between nativity and mortality rate for firms belonging to the manufacturing sector \\
Vit services & Difference between nativity and mortality rate for firms belonging to the tertiary sector \\
Leader mtk share & Highest branch market share in the province held by a single bank/banking group \\
Deposits & Total money deposits with non-monetary institutions \\
\hline
\end{tabular}

Additionally, Italy is characterized by geographical economic and development imbalances. In order not to undervalue this dimension, the bank branches dynamics are explored adopting a macro-regional perspective. The NUTS 1 dimension has been taken into account and regions have been aggregated into two macro-areas: North (including provinces located in North-West and North-East) and South (including Centre, South and Islands) (Note 2).

Even though this subdivision is mainly geographical, when the regions are ranked at an aggregate level by economic performance indicators, the findings show that the most economic developed and richest regions are the Northern ones. The Southern regions have the lowest performance results (Zoia et al., 2018). This division reflects the territorial peculiarities suggested by the empirical literature supporting the idea that North and South are the geographical areas across which Italian economic disparities are most evident (Ciriaci \& Palma, 2008; Montanari, 2011). This is structurally connected to the evolution of the banking system as its development stage is able to drive the economic growth and, in turn, economic development asks for an advanced banking system.

Table 2 summarizes the descriptive statistics of our variables for Italy and distinguishing between the two geographical macro-areas (North and South) traditionally considered to analyse the specific features of the Italian socio-economic environment.

Several differences emerge from the figures included in the table. In particular, the economic gap between the two macro-regions of the country is noticeable; on average, southern provinces have fewer bank branches, deposits and lower value added compared to the corresponding values for provinces located elsewhere. 
Table 2. Descriptive statistics

\begin{tabular}{|c|c|c|c|c|c|c|}
\hline \multirow[b]{2}{*}{ Variable } & \multicolumn{2}{|c|}{$\begin{array}{c}\text { ITALY } \\
\mathrm{N}=1,470 \mathrm{n}=98 \mathrm{~T}=15\end{array}$} & \multicolumn{2}{|c|}{$\begin{array}{c}\text { NORTH } \\
\mathrm{N}=675 \mathrm{n}=45 \mathrm{~T}=15\end{array}$} & \multicolumn{2}{|c|}{$\begin{array}{c}\text { SOUTH } \\
\mathrm{N}=795 \mathrm{n}=53 \mathrm{~T}=15\end{array}$} \\
\hline & Mean & Std. Dev. & Mean & Std. Dev. & Mean & Std. Dev. \\
\hline Branches & 313.23 & 311.88 & 399.03 & 326.27 & 240.38 & 279.33 \\
\hline Elderly index & 33.25 & 5.26 & 34.95 & 5.33 & 31.81 & 4.74 \\
\hline Youth index & 20.86 & 2.16 & 20.28 & 1.95 & 21.35 & 2.20 \\
\hline Pop desert & 0.11 & 0.31 & 0.11 & 0.31 & 0.11 & 0.31 \\
\hline Pop low & 0.54 & 0.50 & 0.47 & 0.50 & 0.59 & 0.49 \\
\hline Pop mid & 0.25 & 0.43 & 0.33 & 0.47 & 0.18 & 0.39 \\
\hline Pop high & 0.10 & 0.31 & 0.09 & 0.29 & 0.12 & 0.32 \\
\hline Value Added & 24.08 & 6.15 & 28.47 & 4.22 & 20.35 & 4.96 \\
\hline Vit primary & -2.32 & 2.03 & -2.46 & 1.91 & -2.19 & 2.13 \\
\hline Vit manufacturing & -2.57 & 1.64 & -2.53 & 1.42 & -2.60 & 1.81 \\
\hline Vit services & 1.43 & 1.72 & 0.95 & 1.53 & 1.84 & 1.76 \\
\hline Leader mkt share & 20.79 & 12.29 & 21.03 & 11.76 & 20.59 & 12.73 \\
\hline Deposits & 12.37 & 26.11 & 13.47 & 19.62 & 11.43 & 30.54 \\
\hline
\end{tabular}

With regard to the industry vitality indexes, there is evidence of a progressive shift towards the tertiary sector; this phenomenon transversally affects the whole country, with the southern provinces showing (on average) the highest values. Finally, population figures for each province reveal a common pattern across the North and the South of Italy. However, it seems that both Elderly and Young Index suggest younger population in the South than in the North.

\section{Empirical Model and Results}

In order to test our hypotheses, using data over the 2000-2016 period for 98 Italian provinces (for a total of 1,470 observations), we employ a dynamic panel model estimator as suggested by Arellano and Bover (1995) and fully developed in Blundell and Bond (1998). In particular, we estimate a linear dynamic panel-data econometric model as follows:

Branches $_{i, t}=\beta_{0}+\beta_{1}$ Branches $_{i, t-1}+\beta_{2}$ Elderly index $_{i, t}+\beta_{3}$ Young index $_{i, t}+\beta_{4}$ Pop low $_{i, t}+\beta_{5}$ Pop mid $_{i, t}+\beta_{6}$ Pop
high $_{i, t}+\beta_{7}$ Value added $_{i, t}+\beta_{8}$ Vit primary $_{i, t}+\beta_{9}$ Vit manufacturing $_{i, t}+\beta_{10}$ Vit services $_{i, t}+\beta_{11}$ Leader mkt share $_{i, t}$
$+\beta_{12}$ Deposits $_{i, t-1}+\gamma$ Time dummies $+\varepsilon_{i, t}$

We opted to drop the dummy related to very small provinces (to avoid the dummy variable trap) as they are almost the least represented (see Table 2). In addition, we included the Deposits in their lagged dimension as they tend to affect the number of branches with a time lag. In addition, deposits tend to be correlated with simultaneous Value Added so this prevents a multicollinearity problem among regressors. Moreover, in order to take into account common macroeconomic shocks and cyclical effects, we also included time-dummies.

To control for endogeneity of the lagged dependent variable and its high persistence, we use a system two-step GMM estimator whose results are reported in Table 3. Regressions treat the lagged Deposits variable as predetermined - by definition (we indeed refer to the value in t-1), while demographic variables (Population, and Elderly and Young indexes), that are supposed to be independent from the number of bank branches, are used as exogenous as well as the Industry vitality and time-dummy variables. Given their close connection with the banking system activities, Value added and Leader market share are considered as potentially endogenous. Finally, the Windmeijer (2005) correction for standard errors is adopted.

To ensure the consistency of the System GMM estimations, we provide some key diagnostics. Firstly, the absence of first and second order serial correlations in the first-differenced residuals was tested using the Arellano and Bond (1991) statistics. Secondly, we referred to the Hansen (1982) test of over-identifying restrictions for the null hypothesis of instrument validity. Thirdly, we utilized the Difference-in-Hansen test for the null hypothesis of the validity of additional moment conditions (Blundell \& Bond, 1998). Finally, we checked that the number of instruments was smaller than or equal to the number of groups in a regression to avoid finite sample bias caused by overfitting (Roodman, 2009).

\subsection{Overall Results}

As revealed by the results shown in Table 3, the coefficient associated with the lagged value of bank branches suggests the presence of a strong autocorrelation. This phenomenon, which has already been tested for with 
reference to bank branch closures (e.g. Tranfaglia, 2018) can be justified on competitive grounds: where many bank branches operate, market entry opportunities can be identified. With reference to Italy, we have to consider the entry into the domestic market of many foreign banks specifically where domestic bank branches are already operating, with the aim of exploiting greater potential for success.

Table 3. Estimation results

\begin{tabular}{|c|c|c|c|}
\hline VARIABLES & $\begin{array}{c}(1) \\
\text { Italy }\end{array}$ & $\begin{array}{c}(2) \\
\text { North }\end{array}$ & $\begin{array}{c}(3) \\
\text { South }\end{array}$ \\
\hline \multirow[t]{2}{*}{ Branches $_{t-1}$} & $0.96^{* * * *}$ & $0.99 * * *$ & $0.95 * * *$ \\
\hline & $(0.041)$ & $(0.022)$ & $(0.070)$ \\
\hline \multirow[t]{2}{*}{ Elderly index } & -1.45 & -2.56 & -1.84 \\
\hline & (1.088) & (2.778) & $(2.326)$ \\
\hline \multirow[t]{2}{*}{ Youth index } & -0.91 & -3.65 & 1.59 \\
\hline & $(1.726)$ & $(4.883)$ & $(2.964)$ \\
\hline \multirow[t]{2}{*}{ Pop low } & -24.59 & 28.79 & -19.46 \\
\hline & $(17.156)$ & $(45.366)$ & (14.845) \\
\hline \multirow[t]{2}{*}{ Pop mid } & $-45.21 * *$ & 11.22 & $-44.40 * *$ \\
\hline & $(19.342)$ & (33.514) & $(18.020)$ \\
\hline \multirow[t]{2}{*}{ Pop high } & -15.80 & 56.38 & -18.47 \\
\hline & $(18.528)$ & (60.658) & (29.284) \\
\hline \multirow[t]{2}{*}{ Value Added } & $2.81 *$ & -1.61 & $5.38 * *$ \\
\hline & $(1.631)$ & $(2.686)$ & $(2.920)$ \\
\hline \multirow[t]{2}{*}{ Vit primary } & $0.79^{*}$ & 0.19 & 0.49 \\
\hline & $(0.416)$ & $(0.692)$ & $(0.539)$ \\
\hline \multirow[t]{2}{*}{ Vit manufacturing } & -1.07 & -0.15 & $-2.10^{*}$ \\
\hline & $(0.780)$ & $(0.655)$ & (1.196) \\
\hline \multirow[t]{2}{*}{ Vit services } & $1.73 * *$ & -0.76 & $3.03 * *$ \\
\hline & $(0.818)$ & $(1.292)$ & $(1.409)$ \\
\hline \multirow[t]{2}{*}{ Leader mkt share } & $-1.50 * * *$ & $-0.87 *$ & $-1.33 * * *$ \\
\hline & $(0.325)$ & $(0.385)$ & $(0.499)$ \\
\hline \multirow[t]{2}{*}{ Deposits $_{t-1}$} & -0.06 & -0.54 & -0.06 \\
\hline & $(0.191)$ & $(0.387)$ & $(0.383)$ \\
\hline \multirow[t]{2}{*}{ Constant } & 74.45 & 188.06 & -33.33 \\
\hline & $(83.336)$ & $(187.652)$ & (118.062) \\
\hline Time-dummies & Yes & Yes & Yes \\
\hline Wald test time-dummies & $105.30 * * *$ & $64.67 * * *$ & $75.54 * * *$ \\
\hline Instruments & 84 & 83 & 84 \\
\hline Hansen J-test & {$[0.009]$} & [0.999] & {$[0.886]$} \\
\hline Diff-in-Hansen test & {$[0.920]$} & [0.999] & [0.999] \\
\hline $\mathrm{AR}(1)$ & {$[0.002]$} & {$[0.002]$} & {$[0.033]$} \\
\hline $\operatorname{AR}(2)$ & {$[0.613]$} & {$[0.732]$} & {$[0.601]$} \\
\hline Observations & 1,470 & 675 & 795 \\
\hline Number of provinces & 98 & 45 & 53 \\
\hline
\end{tabular}

Note. heteroscedasticity-consistent standard errors are in parentheses. Windmeijer (2005) finite sample correction for standard errors is employed. The superscripts *, ** and *** denote significance at the 10\%-, 5\%- and 1\%-level, respectively. The row for the Hansen J-test reports the p-values for the null hypothesis of instrument validity. The values reported for the Diff-in-Hansen test are the p-values for the validity of the additional moment restriction necessary for system GMM. The values reported for AR(1) and AR(2) are the p-values for first and second order autocorrelated disturbances in the first differences equations.

The dependency on elderly and young people has no impact on the bank branches dynamic. Moreover, the size of the resident population does not have a positive monotonic effect on the number of bank branches; on the contrary, a negative relationship is observed for provinces with population between 500,000 and 1 million. In general, the whole number of branches is affected by the many M\&As that have taken place over the years. This tendency, in middle-provinces, prevails over the resident population. 
As expected, the result obtained with reference to the real per capita value added positively affects the number of bank branches in Italy. Therefore, H3 is the first hypothesis to be confirmed.

Our analysis shows that the increase in the number of companies in the manufacturing sector has no impact on the number of bank branches. However, the increase in the number of companies in the primary sector positively affects the number of bank branches. The same occurs for companies in the services sector, which vitality stimulate a greater circulation of cash, positively affecting the number of bank branches.

Referring to the concentration variable, estimates show that it negatively and significatively affects the number of branches suggesting a moral suasion effect of the leader limiting the entry of new competitors and the opening of new branches. Hence, H5 is strongly confirmed.

The result obtained with reference to size of deposits with non-financial institutions is apparently surprising. In fact, contrary to our expectations, the number of bank branches is not significantly affected by deposits increase. However, this result might be justified by the fact that a substantial share of Italians' wealth is invested in tangible assets and in real estate in particular (see Carmignani et al., 2020); this type of asset does not require any bank branches.

Finally, as expected, the number of bank branches is affected by the cyclical dimension. Time-dummies turn out to be jointly significant.

\subsection{North vs South}

Comparing the results obtained from our analysis with reference to the North and the South of Italy, substantial differences emerged. As previously described, econometric outcomes show the presence of a strong autocorrelation in bank branch dynamics; however, as indicated by the coefficients in Table 3 (columns 2 and 3), this effect is stronger in the North than in the South.

The Elderly and Youth proxies have no significant impact on the number of bank branches either in the North or the South of Italy. Moreover, the national demographic dimension seems to be significant due to the Southern-effect, while in the North no significant effects emerge.

The Value Added per capita significantly affects the branch dynamics in the South, while no significance is detected in the North. This suggests a catching-up process of southern provinces where wealth asks for a more capillary banking system physically present in municipalities, while in the northern area the economic system is already in a general efficient pattern and the banking system is more developed and apt to support local economy.

Turning to the vitality variables, the increase in the number of companies in the manufacturing sector has a negative impact on the number of bank branches in the South of Italy. This could be because this kind of companies has generally its administrative headquarters in the North of Italy and this "steals" monetary resources to the provinces of the South. On the contrary, as observed at the national level, the increase in the number of companies in the services sector has a positive impact on the number of bank branches in the southern provinces.

Considering the bank sector variables, the largest market share turns out to be strongly significant in negatively affecting the bank branches dynamics both in the north and in the South, showing a greater coefficient with regard to this latter area. This suggests how a catching-up area is dependent on a strong market concentration which limits competitive strategies and suggests there will be more space for competition in the future.

Finally, the size of non-financial institution deposits does not affect the number of bank branches in both macro-regions.

\section{Discussion and Conclusions}

This study focuses on the bank branch dynamics in Italy also considering the geographical dimension. In our opinion some of the results obtained from our analysis are interesting and deserve comment.

Firstly, the age of Italians does not influence the number of bank branches. This conclusion undermines the idea that the number of bank branches increases when the population is older. Italy certainly has an elderly population (ISTAT, 2020); however, many of them may manage their money through a financial advisor or have delegated to younger people who operate online.

Secondly, (a higher) number of resident inhabitants is no longer a driving factor for growth in the number of bank branches; instead, an inverse relationship is observed. This result, contrary to our expectations, finds its justification in the historical dynamics of bank branches. The most populated areas have always been seen as 
areas of conquest by banks. However, the bank branch rationalization processes implemented following important mergers and acquisitions have reduced the number of branches, especially in areas with higher concentrations.

Thirdly, (higher) Italian per capita wealth is still a reason for the opening of new bank branches. This result, especially valid for the South of Italy, represents a factor of continuity with the past as long as Southern provinces are following a catching-up process with respect to the Northern ones.

The fourth interesting result is that the market share leader tends to reduce the number of branches and this is evident especially in the South. The bank concentration might help the economic development, but it also suggests that bank industry is still under-developed and not as competitive as it should be.

Lastly, our results show that industry vitality plays a role in explaining the dynamics relating to the number of bank branches. However, the relationship is not necessarily positive for all industries; the results obtained show a negative relationship for manufacturing, statistically significant for the southern regions. The hypothesized relationship between these results and governance factors previously reported in the commentary on the econometric results may represent an interesting starting point for future research.

We argue that the results obtained in our analysis are important from at least three points of view. Firstly, the overall results highlight that the variables previously examined and reported in the literature concerning bank branch dynamics (such as age and population) no longer influence the number of bank branches in Italy as they did in the past. Technological innovation, competition rules and the development strategies of domestic and foreign banks have influenced the opening and closing of bank branches. For this reason, researchers will have to identify new drivers in the study of this phenomenon. Secondly, our results highlight the great difference between Northern and Southern Italy and confirm the ISTAT (2020) survey, which highlights a persistent and significant difference between Northern and Southern Italy in terms of income per capita, level of literacy and business attractiveness. This difference, moreover, derives from the interesting economic, financial and social dualism that characterizes the Italian territory, which makes the results of our study extendable to a wide range of economies with different degrees of development.

Finally, the results appear interesting for local policymakers. In fact, the dynamics observed suggest that the lack of attractive factors for the establishment of bank branches risks generating adverse effects on economically peripheral regions. The main risks can be identified in the reduction of employment in the financial sector, in a lesser ability of companies to entertain relationship lending relationships with banks and, more generally, in a deterioration of the finance-growth link. From this point of view, actions aimed at stimulating the growth of business sectors that prove to be attractive to banks (such as the tertiary sector), appear useful for stimulating new banking settlements, with all the benefits deriving from this result.

\section{References}

Agarwal, S., \& Hauswald, R. (2010). Distance and private information in lending. The Review of Financial Studies, 23(7), 2757-2788. https://doi.org/10.1093/rfs/hhq001

Alamá Sabater, L., Conesa Guillén, D., Forte Deltell, A., \& Tortosa-Ausina, E. (2013). A Bayesian perspective to analyze branch location patterns in Spanish Banking (No. 2013127). Fundacion BBVA/BBVA Foundation. https://www.fbbva.es/wp-content/uploads/2017/05/dat/DT\%203_2013_web.pdf

Alamá Sabater, L., Conesa, D., Forte Deltell, A., \& Tortosa-Ausina, E. (2015). The geography of Spanish bank branches. Journal of Applied Statistics, 42(4), 722-744. https://doi.org/10.1080/02664763.2014.980792

Alamá, L., \& Tortosa-Ausina, E. (2012). Bank Branch Geographic Location Patterns in Spain: Some Implications for Financial Exclusion. Growth and Change, 43(3), 505-543. https://doi.org/10.1111/j.1468-2257.2012.00596.x

Arellano, M., \& Bover, O. (1995). Another look at the instrumental variable estimation of error-components models. Journal of Econometrics, 68(1), 29-51. https://doi.org/10.1016/0304-4076(94)01642-D

Arellano, M., \& Bond, S. (1991). Some tests of specification for panel data: Monte Carlo evidence and an application to employment equations. Review of Economic Studies, 58(2), 277-297. https://doi.org/10.2307/2297968

Argent, N. M., \& Rolley, F. (2000). Financial exclusion in rural and remote New South Wales, Australia: A geography of bank branch rationalisation, 1981-98. Australian Geographical Studies, 38(2), 182-203. https://doi.org/10.1111/1467-8470.00110

Barreto, I., \& Baden-Fuller, C. (2006). To conform or to perform? Mimetic behaviour, legitimacy-based groups 
and performance consequences. Journal of Management Studies, 43(7), 1559-1581. https://doi.org/10.1111/j.1467-6486.2006.00620.x

Blundell, R., \& Bond, S. (1998). Initial conditions and moment restrictions in dynamic panel data models. Journal of Econometrics, 87(1), 115-143. https://doi.org/10.1016/S0304-4076(98)00009-8

Brevoort, K. P., \& Hannan, T. H. (2006). Commercial lending and distance: evidence from Community Reinvestment Act data. Journal of Money, Credit and Banking, 1991-2012. https://doi.org/10.1353/mcb.2007.0000

Burgstaller, J. (2013). Bank office outreach, structure and performance in regional banking markets. Regional Studies, 47(7), 1131-1155. https://doi.org/10.1080/00343404.2011.607809

Calcagnini, G., De Bonis, R., \& Hester, D. D. (1999). Determinants of bank branch expansion in Italy. Social Systems Research Institute, University of Wisconsin.

Carmignani, A., Manile, M., Orame, A., \& Pagnini, M. (2020). Online banking services and branch networks. Questioni di Economia e Finanza (Occasional Papers) 543, Bank of Italy, Economic Research and International Relations Area.

Chang, A., Chaudhuri, S., \& Jayaratne, J. (1997). Rational herding and the spatial clustering of bank branches: an empirical analysis. Department of Economics Discussion Papers, 9697-24. https://econpapers.repec.org/RePEc:fip:fednrp:9724

Chen, H., \& Strathearn, M. (2020). A Spatial Model of Bank Branches in Canada. Bank of Canada Staff Working Paper, 2020-4. https://doi.org/10.1108/S0731-905320200000042012

Ciriaci, D., \& Palma, D. (2008). The role of knowledge-based supply specialisation for competitiveness: A spatial econometric approach. Papers in Regional Science, 87(3), 453-475. https://doi.org/10.1111/j.1435-5957.2008.00198.x

Coccorese P. (2012). Il potenziale di espansione del credito cooperativo: Un'analisi territorial. In A. Amendola (Ed.), Progetto aree bianche. Il sistema del credito cooperativo in Campania, ECRA, Romea.

Coccorese, P., \& Santucci, L. (2020). Banking competition and bank size: Some evidence from Italy. Journal of Economics and Finance, 44(2), 278-299. https://doi.org/10.1007/s12197-019-09488-2

Cohen, A., \& Mazzeo, M. J. (2010). Investment strategies and market structure: An empirical analysis of bank branching decisions. Journal of Financial Services Research, 38(1), 1-21. https://doi.org/10.1007/s10693-010-0082-7

Crawford, R. J. (1973). A comparison of the internal urban spatial pattern of unit and branch bank offices. The Professional Geographer, 25(4), 353-356. https://doi.org/10.1111/j.0033-0124.1973.00353.x

Dante, H., \& Makridis, C. (2021). The Rise of Mobile Banking and the Displacement of Brick-and-Mortar Branches, 2014-2019. http://dx.doi.org/10.2139/ssrn.3822561

Degryse, H., \& Ongena, S. (2005). Distance, lending relationships, and competition. The Journal of Finance, 60(1), 231-266. https://doi.org/10.1111/j.1540-6261.2005.00729.x

Degryse, H., Kim, M., \& Ongena, S. (2009). Microeconometrics of banking: Methods, applications, and results. USA: Oxford University Press. https://doi.org/10.1093/acprof:oso/9780195340471.001.0001

Ding, L., \& Reid, C. K. (2020). The Community Reinvestment Act (CRA) and Bank Branching Patterns. Housing Policy Debate, 30(1), 27-45. https://doi.org/10.1080/10511482.2019.1665836

Elyasiani, E., \& Goldberg, L. G. (2004). Relationship Lending: A Survey of the Literature. Journal of Economics and Business, 56, 315-330. https://doi.org/10.1016/j.jeconbus.2004.03.003

Felici, R., \& Pagnini, M. (2008). Distance, bank heterogeneity and entry in local banking markets. The Journal of Industrial Economics, 56(3), 500-534. https://doi.org/10.1111/j.1467-6451.2008.00357.x

Hansen, L. P. (1982). Large sample properties of generalized method of moments estimators. Econometrica, 50(4), 1029-1054. https://doi.org/10.2307/1912775

He, C., \& Yeung, G. (2011). The locational distribution of foreign banks in China: A disaggregated analysis. Regional Studies, 45(6), 733-754. https://doi.org/10.1080/00343401003614282

Ho, K., \& Ishii, J. (2011). Location and competition in retail banking. International Journal of Industrial Organization, 29(5), 537-546. https://doi.org/10.1016/j.ijindorg.2010.11.004 
Hotelling, H. (1929). Stability in Competition. The Economic Journal, 39(153), 41-57. https://doi.org/10.2307/2224214

Huysentruyt, M., Lefevere, E., \& Menon, C. (2013). Dynamics of retail-bank branching in Antwerp (Belgium) 1991-2006: Evidence from micro-geographic data. Journal of Banking \& Finance, 37(2), 291-304. https://doi.org/10.1016/j.jbankfin.2012.08.023

King, R. G., \& Levine, R. (1992). Financial indicators and growth in a cross section of countries (Vol. 819). World Bank Publications. https://econpapers.repec.org/RePEc:wbk:wbrwps:819

ISTAT. (2020). Annual report 2020. Istituto nazionale di statistica, Rome.

Leyshon, A., French, S., \& Signoretta, P. (2008). Financial exclusion and the geography of bank and building society branch closure in Britain. Transactions of the Institute of British Geographers, 33(4), 447-465. https://doi.org/10.1111/j.1475-5661.2008.00323.x

Montanari, M. (2011). Italy's regional divide: Does matter also for exports. ECFIN Country Focus, 8(2), 1-7.

Okeahalam, C. (2009). Bank branch location: A count analysis. Spatial Economic Analysis, 4(3), 275-300. https://doi.org/10.1080/17421770903114695

Peterson, M., \& Rajan, R. (2002). The Benefits of Lending Relationships: Evidence from Small Business Data. Journal of Finance, 3-37. https://doi.org/10.1111/j.1540-6261.1994.tb04418.x

Qi, S., De Haas, R., Ongena, S. R. G., \& Straetmans, S. (2019). Move a Little Closer? Information Sharing and the Spatial Clustering of Bank Branches. Swiss Finance Institute Research Paper, 17-74. https://doi.org/10.2139/ssrn.3099119

Richards, T. J., Acharya, R. N., \& Kagan, A. (2008). Spatial competition and market power in banking. Journal of Economics and Business, 60(5), 436-454. https://doi.org/10.1007/978-3-642-23062-2_34

Roodman, D. (2009). A note on the theme of too many instruments. Oxford Bulletin of Economics and Statistics, 71(1), 135-158. https://doi.org/10.1111/j.1468-0084.2008.00542.x

Salop, S. C. (1979). Monopolistic competition with outside goods. The Bell Journal of Economics, 10(1), 141-156. https://doi.org/10.2307/3003323

Sengupta, R., \& Dice, J. (2019). Did local factors contribute to the decline in bank branches? Economic $\begin{array}{lllll}\text { Review-Federal Reserve Bank of Kansas } & \text { City, }\end{array}$ https://doi.org/10.18651/ER/3q19SenguptaDice

Stix, H. (2020). The Austrian bank branch network from 2000 to 2019 from a spatial perspective. Financial Stability Report, 87-101.

Windmeijer, F. (2005). A finite sample correction for the variance of linear efficient two-step GMM estimators. Journal of Econometrics, 126(1), 25-51. https://doi.org/10.1016/j.jeconom.2004.02.005

Zoia, M. G., Barbieri, L., Cortelezzi, F., \& Marseguerra, G. (2018). The determinants of Italian firms' technological competencies and capabilities. Eurasian Business Review, 8(4), 453-476. https://doi.org/10.1007/s40821-018-0103-2

\section{Notes}

Note 1. https://www.infocamere.it/movimprese.

Note 2. In the NUTS codes, ITC and ITH NUTS1 regions belong to the North, while ITI, ITF and ITG belong to the South.

\section{Copyrights}

Copyright for this article is retained by the author(s), with first publication rights granted to the journal.

This is an open-access article distributed under the terms and conditions of the Creative Commons Attribution license (http://creativecommons.org/licenses/by/4.0/). 